\title{
多環芳香族炭化水素の微生物処理
}

\author{
峯木 茂 ${ }^{1)}$, 杉田 和俊 ${ }^{2)}$, 後藤 純雄 ${ }^{3)}$, \\ 渡辺 征夫 ${ }^{3)}$, 溝口 次夫 $^{3)}$, \\ 石井 忠浩 ${ }^{4}$, 飯田 貢 ${ }^{1)}$ \\ ${ }^{1)}$ 東京理科大学理工学部応用生物科学科（テ278 野田市川崎2641） \\ ${ }^{2}$ (財)日本品質保証機構（テ140 品川区東大井1-8-12） \\ ${ }^{3)}$ 国立公衆衛生院（テ108 港区白金台4-6-1） \\ ${ }^{4}$ 東京理科大学理学部応用化学科（₹162 新缩区神楽坂1-3）
}

[平成 6 年 8 月 8 日受理］

\section{Microbial Degradation of Polycyclic Aromatic Hydrocarbons}

\author{
Shigeru MINEKI ${ }^{1)}$, Kazutoshi SUGITA ${ }^{2)}$, Sumio GOTO ${ }^{3)}$, Ikuo WATANABE ${ }^{3)}$ \\ Tsuguo MIZOGUCHI ${ }^{3)}$, Tadahiro ISHII $^{4)}$ and Mitsugi IIDA ${ }^{1)}$ \\ ${ }^{1)}$ Department of Applied Biological Science, Science University of Tokyo (2641 Yamazaki, \\ Noda, Chiba 278) \\ 2) Japan Quality Assurance Organization (1-8-12 Higashi-ohi, Shinagawa-ku, Tokyo 140) \\ 3) National Institute of Public Health (4-6-1 Shirokanedai, Minato-ku, Tokyo 108) \\ 4) Department of Applied Chemistry, Science University of Tokyo (1-3 Kagurazaka, Shinjuku- \\ ku. Tokyo 162)
}

[Received August, 8, 1994]

\section{Summary}

Strain $\mathrm{H} 2-5$, a gram positive and rod bacterium which was capable of degrading pyrene, was isolated from soil. The bacterium was positive for acid-fast staining. The optimum growth temperature was $34.3^{\circ} \mathrm{C}$, and the upper limit temperature for the growth was around $45^{\circ} \mathrm{C}$. At low concentration $(1.3 \mu \mathrm{g} / \mathrm{ml})$ of polycyclic aromatic hydrocarbons (PAHs), $\mathrm{H} 2-5$ cells $(45 \mu \mathrm{g}$ dry weight $/ \mathrm{ml}$ ) grown on TSB degraded $90 \%$ of pyrene in $12 \mathrm{hr}$, and degraded $60 \%$ of Benzo (a) pyrene $(\mathrm{BaP}), 25 \%$ of Benz (a) anthracene $(\mathrm{BaA})$, and $8 \%$ of Benzo (ghi) perylene (BghiP) in 3 days. At high concentration $(26.7 \mu \mathrm{g} / \mathrm{ml})$ of PAHs, $\mathrm{H} 2-5$ cells $(226 \mu \mathrm{g}$ dry weight $/ \mathrm{ml})$ grown on TSB degraded more than $80 \%$ of pyrene and $\mathrm{BaP}, 40 \%$ of $\mathrm{BaA}$, and $30 \%$ of $\mathrm{BghiP}$ in 11 days. Mixture of cells $(5.4 \mu \mathrm{g}$ dry weight/ml) grown on pyrene-enriched culture, from which $\mathrm{H} 2-5$ was isolated, degraded pyrene more rapidly at early reaction stage, but less effectively at later stage, than the isolated $\mathrm{H} 2-5$ (226 $\mu \mathrm{g}$ dry weight/ml) grown on TSB, and both degraded $90 \%$ of pyrene in 11 days.

Key words: Pyrene-assimilating bacterium, Benzo (a) pyrene degradation, Benz (a) anthracene, Benzo (ghi) perylene, Polycyclic aromatic hydrocarbons, 


\section{1.はじめに}

多環芳香族炭化水素（PAH）は，マイコトキシン, ニトロソアミンなどと並んで重要な環境発癌関連物質群 を構成しており，化石燃料など各種有機物の不完全燃焼 から容易に生成するため環境中に広く分布し，エネル ギー消費の拡大に伴ってその環境濃度が増加していると 考えら机る。この不完全燃焼から生成したPAH 類は大 気中へ放出され，それらを含む大気浮遊粉塺の多くは地 表に落下して土壤を污染している1-2)。従って, 污染筒 所の修復・改善（remediation）は環境発癌対策上極め て重要である。

微生物によるPAHの分解に関しては, ここ数年飛躍 的に研究成果が蓄積しているが, それらは主にナフタレ ン, ビフェニール，アントラセン，およびフェナントレ ンに関してであって，4 環以上の芳香環を含むPAHの 微生物分解に関する研究は極めて不十分である。即ち, ピレンを資化する細菌としては, Heitkamp ら ${ }^{31}$ や Boldrin ら ${ }^{4} の$ Mycobacterium sp. や, Walter $ら^{5)}$ の Rhodococcus sp. などの報告があるだけであり，また，ベンゾ(a)ピレンの 酸化分解に関してはGibson $ら^{6 /}$ の Beijerinckia sp. や, Bumpus ら゙の Phanerochaete chrvsosporium などの報告があ るにすぎない。

本研究は, 環境発癌関連物質の環境中での挙動および 処理対策に関する研究の一環として, 土壤からピレンを 資化する微生物を分離し, その生育条件や各種 PAH 類 の分解性を検討したものである。

\section{2. 方法}

\section{1 使用培地}

無機液体培地：Kiyohara $5^{8)}$ の培地を参考として, $0.1 \% \mathrm{Na}_{2} \mathrm{HPO}_{4} \cdot 12 \mathrm{H}_{2} \mathrm{O}, 0.05 \% \mathrm{KH}_{2} \mathrm{PO}_{4}, 0.15 \%\left(\mathrm{NH}_{4}\right)_{2} \mathrm{SO}_{4}$, $0.1 \% \mathrm{NH}_{4} \mathrm{Cl}, \quad 0.05 \% \mathrm{MgSO}_{4} \cdot 7 \mathrm{H}_{2} \mathrm{O}, \quad 0.05 \% \mathrm{NaCl}$, $0.0015 \% \mathrm{CaCl}_{2} \cdot 2 \mathrm{H}_{2} \mathrm{O}, 0.001 \% \mathrm{FeCl}_{3} \cdot 6 \mathrm{H}_{2} \mathrm{O}, \mathrm{pH} 7.0$ に調製した。

TSB 液体培地：Tryptic Soy Broth（Difco）30g を蒸留 水 11 に溶解して調製した。

平板（寒天）培地：それぞれの培地に寒天を $1.5 \%$ 加 えた。

ピレン塗布培地：ピレンをnへキサン/アセトン $=1$ $: 1^{9)}$ に溶解し $(20 \mathrm{mg} / \mathrm{ml})$, その $0.5 \mathrm{ml}$ を無機平板培地 に塗布後, $30^{\circ} \mathrm{C}$ 灾卵器に一晚入れて有機溶媒を蒸発さ せてから使用した。

\section{2 微生物の分融}

土壤試料 $1 \mathrm{~g}$ を滅菌水 $9 \mathrm{ml}$ に加之, 十分擋找後希釈し, 上澄み $0.1 \mathrm{ml}$ を無機液体培地 $10 \mathrm{ml}$ とピレン $(0.4 \mathrm{mg}$ を N,N-ジメチルホルムアミド（DMFA） $0.02 \mathrm{ml}$ に溶解し

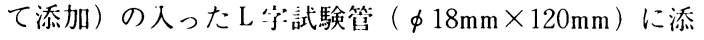
加して $30^{\circ} \mathrm{C} 、 100 \mathrm{rpm}$ でインキュベートした。活性は, $365 \mathrm{~nm}$ の紫外線下のピレンの蛍光が消尖することを指標 に検出した。活性の見られた培養液はさらに 2 回ピレン で集積培養をくりかえした後，培養液を適宜希釈し，そ

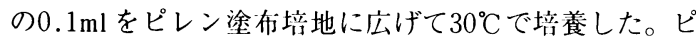
レンを溶かしてクリアゾーンを作るコロニーを滅菌水に 愳濁し, 同様な操作を繰り这し, さらにTSB平板培地 を用いて単一コロニーを得た。

\section{3 微生物の培䕊}

得られた単一コロニー（H2-5株）をTSB 液体培地 $10 \mathrm{ml}$ の入った L 字試験管で前培養し $\left(30^{\circ} \mathrm{C}, 100 \mathrm{rpm}\right)$, $0.2 \mathrm{ml}$ を植え継いで同条件下に本培養を行い, 生育が定 常期（ 5 days）になったところで集菌・洗浄し（9,000 $\times \mathrm{g})$ ，以下の実験に供した。また，集積培養菌（H2-5 株分離以前の混合菌：H2菌）を無機液体培地にて，ピ レン $(1.0 \mathrm{mg} / 0.05 \mathrm{ml}$ DMFA）を添加して培養し, 定 常期（10days）で集菌・洗浄して用いた。なお，生育測 定は660nm の吸光度を測定することによって行った。

\section{4 微生物によるPAHの処理}

4 本の L 字試験管にそれぞれ $15 \mathrm{ml}$ の無機液体培地を 入れ, ピレン, ベンツ (a) アントラセン $(\mathrm{BaA})$, ベン ゾ(a)ピレン $(\mathrm{BaP})$, およびベンゾ $(\mathrm{ghi})$ ペリレン $(\mathrm{BghiP})$ の各DMFA 溶液を別々に一定量添加した。2.3で得た 菌体を一定量の無機液体培地に懸濁し、それぞれに $0.3 \mathrm{ml}$ 加え, $30^{\circ} \mathrm{C}, 70 \mathrm{rpm}$ で振盪した。経時的に, $0.5 \mathrm{ml}$ を試料バイアルに抜き取り, $\mathrm{PAH}$ 分析までー $20^{\circ} \mathrm{C}$ で保存した。なお，加えた菌体量は洗浄後の菌体を $100^{\circ} \mathrm{C}$ で12時間乾燥し, 乾燥菌体重量として表した。

\section{5 PAH 漕度の測定}

処理後の保存試料（それぞれ別々のPAHを含む）か ら $0.05 \mathrm{ml}$ を採取し，アセトニトリルで $10^{2}-10^{3}$ 倍に希釈 し, 日立850型分光蛍光光度計を用いて各 $\mathrm{PAH} の$ 最適励 起波長执よび蛍光波長（ピレン：Ex. 339nm, Em. 373nm; BaA : 292nm, 412nm; BaP : 370nm, 406nm; BghiP：370nm, 406nm）を選んで蛍光光度を測定し, PAH 添加直後からの相対濃度を求めた。

\section{3. 結果・考察}

\section{1 ピレン資化性微生物の分離}

1993年 7 月に都内および野田市の土猿約 20 試料をサン プリングしてピレン分解活性を検索した結果，東京都港 区白金台（国立公衆衛生院近辺）の土壌の一つに比較的 活性の高い試料を見いだした。本試料から上記の方法に より単一コロニーを取得し,これを分離菌 H2-5株とし 
た。H2-5株はピレン添加時の量の溶媒（DMFA）だけ ではほとんど生育せず, ピレンを唯一の炭素源として生 育できるピレン資化性菌と考えられる。H2-5株の位相 差顕微鏡写真をFig. 1に, また, ピレン塗布培地での本 菌株によるクリアゾーンの形成をFig. 2に示した。

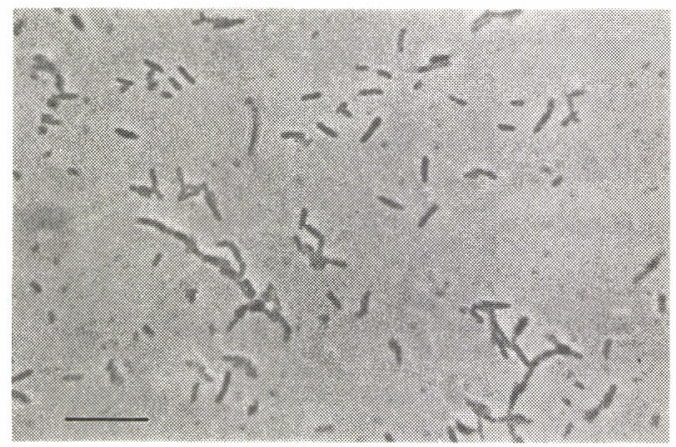

Fig. 1 Phase-contrast photomicrograph of H2-5. $\mathrm{H} 2-5$ was cultivated on mineral salts agar medium with pyrene at $30^{\circ} \mathrm{C}$ for 2 weeks. Bar in the figure shows $10 \mu \mathrm{m}$.

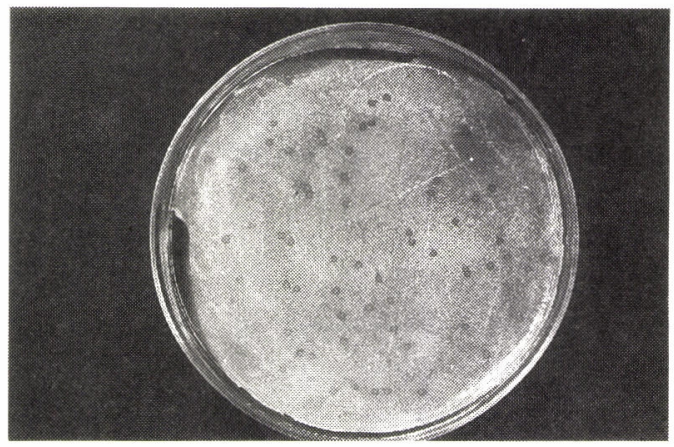

Fig. 2 Utilization of pyrene by $\mathrm{H} 2-5$ on mineral salts agar plate. After the plate was coated a solution of pyrene, H2-5 was inoculated and then incubated for 3 weeks.

\section{3. $2 \mathrm{H} 2-5$ 株の性質}

本菌株はグラム陽性桿菌で，抗酸性染色陽性であり， いわゆる acid-fast bacteriaであった。TSB 寒天培地で黄 色の小コロニーを形成し，植菌後新たなコロニーの確認 には $30^{\circ} \mathrm{C} て ゙ 4-5$ 日を要した。ピレン塗布培地では 1 週 間が必要であった。ピレン資化性菌として報告のある Heitkamp ら ${ }^{31}$ の Mycobacterium sp. はその資化に少量のぺ プトン，酵扗エキス，扮よび糖を必要とするので本菌株 とは異なっている。一方, Boldrin ${ }^{4)}$ の Mycobacterium sp. strain BB1 や, Walter ら ${ }^{5)}$ の Rhodococcus sp. UW1は
ピレンを唯一の炭素源として資化するので本菌株と類似 している。

\section{3. $3 \mathrm{H} 2-5$ 株の生育に及ぼす温度の影響}

H2-5株をTSB 培地で振璗温度勾配培養装置（アドバ ンテック東洋 TN-3型，L字試験管 $(\phi 16 \mathrm{~mm} \times 180 \mathrm{~mm})$ 培養) を用い, 種々の温度 $\left(16.7-61.7^{\circ} \mathrm{C}, 30 \mathrm{rpm}\right)$ で 7 日間培養して生育に対する温度の影響を検討した。得 られた結果のうち，代表的な生育曲線をFig. 3に示した が, 最適温度は $34.3^{\circ} \mathrm{C}$ であり 5 日で定常期に達した。低

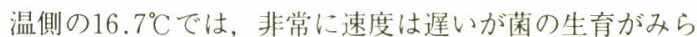

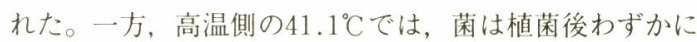
生育したのち減少したが, $46.6^{\circ} \mathrm{C}$ 以上では植菌後減少す るのみであった。

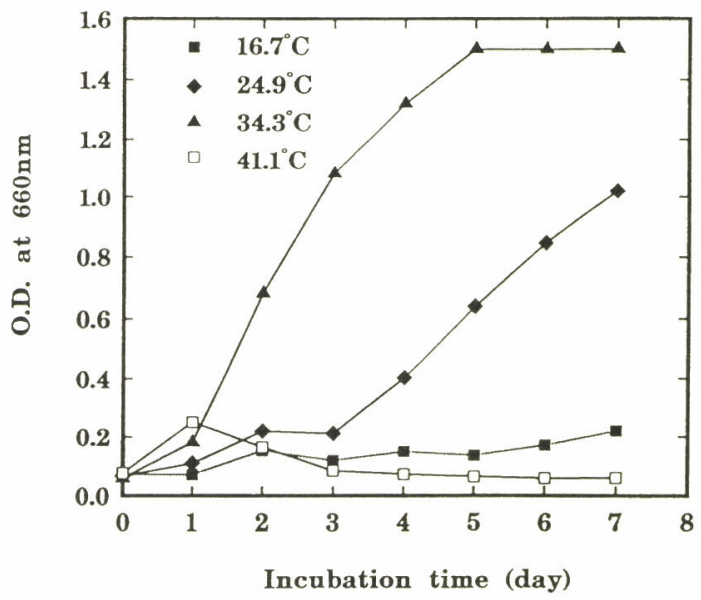

Fig. 3 Growth of $\mathrm{H} 2-5$ on TSB at various tempera. tures. H2-5 was cultivated in L-shaped test tube with $30 \mathrm{rpm}$ on a temperature gradient incubator.

\section{3. $4 \mathrm{H} 2-5$ 株による低濃度 PAHの分解}

Fig. 4 は分離菌H2-5株を TSB 液体培地で培養後, 菌 体濃度 $45 \mu \mathrm{g} / \mathrm{ml}$ で各種 PAH $(1.3 \mu \mathrm{g} / \mathrm{ml}$ 培地) を分解さ せたときの経時変化を残存率で表したものである。ピレ ンは速やかに分解された $(12 \mathrm{hr} て ゙$ 約 $90 \%)$ が, $\mathrm{BaP}$ 3 日で約 $60 \%$ の分解であった。また, BaA と BghiPは 3 日でそれぞれ約 $25 \%$ と約 $8 \%$ 分解されたのみであり, H2-5株は BaPを比較的分解しやすく, BaA および BghiPは分解しにくいことが分かった。これは本菌がピ レン資化性菌であり, $\mathrm{BaP}$ が他の 2 種の $\mathrm{PAH}$ に比べて, 構造上ピレンに類似しているためと思われ，H2-5株の $\mathrm{PAH}$ 分解酵素（酸化酵素など）の基質特異性を反映し ているものと考えられる。 


\section{3. $5 \mathrm{H} 2-5$ 株による高銥度 PAH の分解}

$\mathrm{H} 2-5$ 株は高濃度 $(200 \mu \mathrm{g} / \mathrm{ml}$ 培地) のピレンにも生育 するので, 他のPAHに対してもかなり高濃度でも分解 すると考えられた。そこで, PAH $(26.7 \mu \mathrm{g} / \mathrm{ml}$ 培地 $)$

を菌体濃度 $226 \mu \mathrm{g} / \mathrm{ml}$ で分解を行った。結果を Fig. 5 に
示したが，基質の添加量が多く，基質が多量に析出した ため反応初期はデー夕の振れがみられた。ピレンの場合, その後徐々に分解され，反応 11 日目で $80 \%$ 以上が分解さ れた。その他の PAH も反応 2 日目までは良好に分解さ れ，BaPは11日目にはピレンと同様に $80 \%$ 以上が分解さ

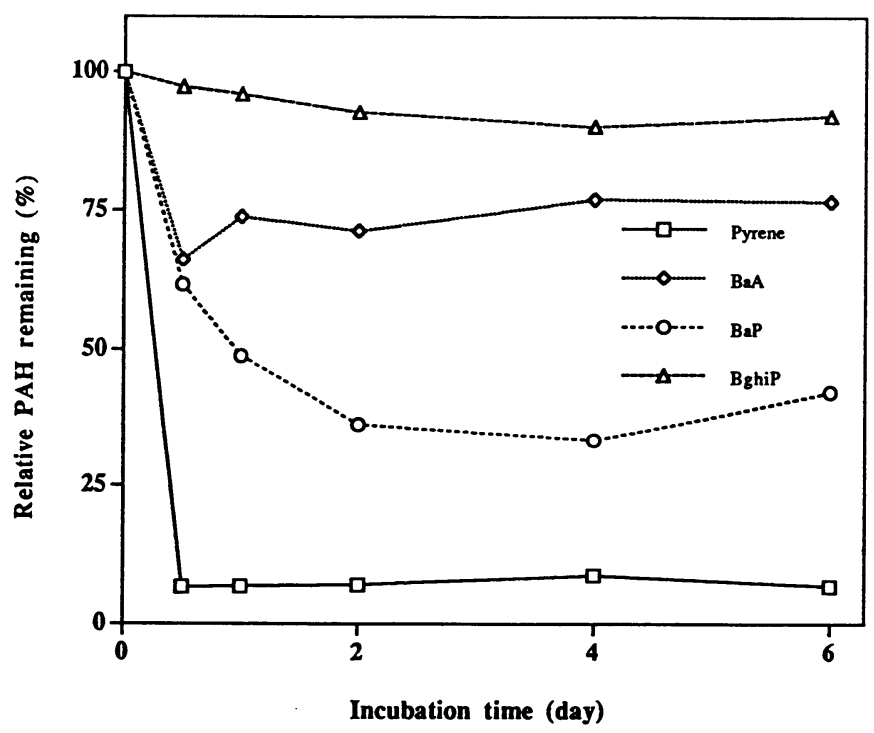

Fig. 4 Rate of degradation of four PAHs by H2-5 grown on TSB. After each PAH was added to the mineral medium at the concentration of $1.3 \mu \mathrm{g} / \mathrm{ml}, \mathrm{H} 2-5$ cells $(45 \mu \mathrm{g}$ dry weight/ml) were inoculated and then incubated at $30^{\circ} \mathrm{C}$ for 4 days.

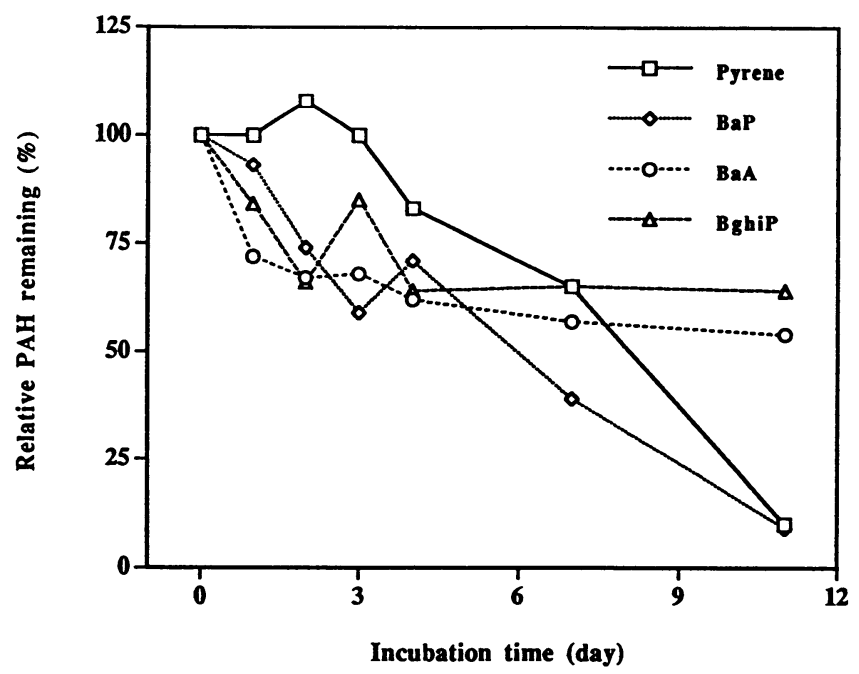

Fig. 5 Degradation of high concentration of PAHs by H2-5 grown on TSB. After each PAH was added to the mineral medium at the concentration of $26.7 \mu \mathrm{g} / \mathrm{ml}, \mathrm{H} 2-5$ cells $(226 \mu \mathrm{g}$ dry weight $/ \mathrm{ml}$ ) were inoculated and then incubated at $30^{\circ} \mathrm{C}$ for 11 days. 
れた。しかし，BaAに対してはその後の速度が急激に 低下し, 約 40\%の分解となり，また，BghiPに対しては 2 日目以後の伸びは見られず約 $30 \%$ の分解に留まった。

3. 項で得られた結果と傾向は似ているが, 多量に析出 した基質と菌との接触，吸着の問題や，基質濃度が高く 反応時間も長いために起こるであろう菌の増殖の問題な どが異なると考えられるので，これらの結果を単純には 比較できない。

\section{3. $6 \mathrm{H} 2$ 菌によるピレンの分解}

活性污泥による有機物の分解にみられるように，直接 分解に与る菌以外の共存菌・混在菌がその作用を助けた り，妨害したりすることがある。また，H2-5株による 環境修復（bioremediation）を考えた場合，フィールド での混在菌の作用の問題が生じるが，それを考える上で の一つのモデルとして, ピレン-無機液体培地で集積培 養した $\mathrm{H} 2-5$ 株分離前の混合菌である $\mathrm{H} 2$ 菌（菌体濃度 $5.4 \mu \mathrm{g} / \mathrm{ml}$ ) を用いてピレンの分解を行い，H2-5株で得 られた結果 (3.5 項) と比較した。Fig. 6に示したように, 反応初期の分解は菌体濃度がかなり低いにもかかわらず H2-5株よりも速かった。その後は徐々に速度が鈍り, 11日目ではH $2-5$ 株と同様の分解率を示すに留まった。 また, 後期の分解速度は, むしろ純粋分離された $\mathrm{H} 2-5$ 株の方が高くなった。このような高濃度の系では分解に 長時間を要するため, H2-5株の活性の誘導が生じ, 反

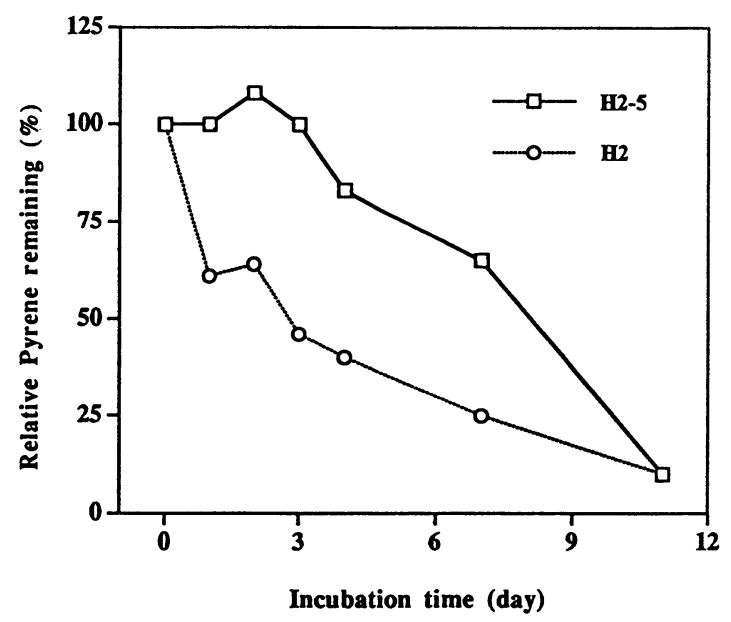

Fig. 6 Degradation of high concentration of pyrene by $\mathrm{H} 2$ grown on pyrene and $\mathrm{H} 2-5$ grown on TSB. After pyrene $(26.7 \mu \mathrm{g} / \mathrm{ml})$ was added to the mineral medium, $\mathrm{H} 2$ cells ( 5.4 $\mu \mathrm{g}$ dry weight $/ \mathrm{ml}$ ) or $\mathrm{H} 2-5$ cells $(226 \mu \mathrm{g}$ dry weight $/ \mathrm{ml}$ ) were inoculated and then in cubated at $30^{\circ} \mathrm{C}$ for 11 days.
応後期で同様な分解率を示したということも考えられ る。H2菌はピレンで培養されたため, 反応初期は分解 活性が誘導強化されていたと考えられるが, 反応後期の 分解速度低下とともに今後の検討が必要である。

\section{要 約}

土壤よりピレンを資化するグラム陽性桿菌 H2-5株を 単離し, 土壤中にPAH 類を分解する微生物が存在する 事を示した。本菌は抗酸性染色陽性で, 生育の最適温度 は $34.3^{\circ} \mathrm{C}$, 上限温度は $45^{\circ} \mathrm{C}$ 付近であった。 TSB 培地で 生育した $\mathrm{H} 2-5$ 株は菌体（乾燥重量）濃度 $45 \mu \mathrm{g} / \mathrm{ml}$ で低 濃度 $(1.3 \mu \mathrm{g} / \mathrm{ml})$ のピレンを 12 時間の処理で $90 \%$ 分解し, 同濃度の $\mathrm{BaP}, \mathrm{BaA}$ ，およびBghiPを 3 日間の処理で, それぞれ $60 \%, 25 \%$ ，および $8 \%$ 分解した。また, 高濃 度 $(26.7 \mu \mathrm{g} / \mathrm{ml})$ のPAHでは, TSB培地で生育した H2-5株は菌体濃度 $226 \mu \mathrm{g} / \mathrm{ml}$ でピレンを11日の処理で $80 \%$ 以上分解し, $\mathrm{BaP}, \mathrm{BaA}$, および BghiP 同様の処 理で，それぞれ $80 \%$ 以上，40\%，および30\%分解した。 ピレン一無機液体培地で生育した, 混在菌を含む $\mathrm{H} 2$ 菌 (菌 体濃度 $5.4 \mu \mathrm{g} / \mathrm{ml}$ ) による高濃度のピレンの処理では, 上記 TSB 培地で生育した H2-5株に比べ, 初期の分解速 度は高かったが, 後期では遅くなり, 11日目の分解率に 差はみられなかった。

\section{文 献}

1）松下秀鶴, 加藤幸彦, 久松由東: 大気污染学会誌, 15，348-352（1980）

2) 西村哲治, 後藤純雄, 加藤幸彦, 奥貫正美, 松下秀 鶴：大気污染学会誌，19，228-238 (1984)

3) Heitkamp, M. A., Franklin, W., and Cerniglia, C. E.,: Microbial metabolism of polycyclic aromatic hydrocarbons: isolation and characterization of a pyrenedegrading bacterium. Appl. Environ. Microbiol., 54, 2549-2555 (1988)

4) Boldrin, B., Tiehm, A., and Fritzsche, C.,: Degradation of phenanthrene, fluorene, fluoranthene, and pyrene by a Mycobacterium sp. Appl. Environ. Microbiol., 59, 1927-1930 (1993)

5) Walter, U., Beyer, M., Klein, J., and Rehm, H. J.,: Degradation of pyrene by Rhodococcus sp. UW1. Appl. Microbiol. Biotechnol., 34, 671-676 (1991)

6) Gibson, D. T., Mahadevan, V., Jerina, D. M., Yagi, H., and Yeh, H. J. C.,: Oxidation of the carcinogens benzo [a]pyrene and benzo[a] anthracene to dihydrodiols by a bacterium. Science, 189, 295-297 (1975)

7) Bunpus, J. A., Tien, M., Wright, D., and Aust, S. D.,: Oxidation of persistent environmental pollutants by a white rot fungus. Science, 228, 1434-1436 (1985) 
8) Kiyohara, H., Nagao, K., and Yano, K.,: Rapid screen for bacteria degrading water-insoluble, solid hydrocarbons on agar plates. Appl. Environ. Microbiol., 43, 454-457 (1982)
9) Heitkamp, M. A. and Cerniglia, C. E.,: Mineralization of polycyclic aromatic hydrocarbons by a bacterium isolated from sediment below an oil field. Appl. Environ. Microbiol., 54, 1612-1614 (1988) 